\title{
Biological Control of Insect Pests of Medicinal Plants - Abelmoschus moschatus, Gloriosa superba and Withania somnifera in Forest Nursery and Plantation in Madhya Pradesh, India
}

\section{Premanand Balkrishna Meshram, Nahar Singh Mawai, Ramkumar Malviya}

Forest Entomology Division, Tropical Forest Research Institute (ICFRE), Jabalpur, India

Email address:

meshrampb@icfre.org (P. B. Meshram)

To cite this article:

Premanand Balkrishna Meshram, Nahar Singh Mawai, Ramkumar Malviya. Biological Control of Insect Pests of Medicinal Plants Abelmoschus moschatus, Gloriosa superba and Withania somnifera in Forest Nursery and Plantation in Madhya Pradesh, India. American Journal of Agriculture and Forestry. Vol. 3, No. 2, 2015, pp. 47-51. doi: 10.11648/j.ajaf.20150302.16

\begin{abstract}
The present investigation was carried out to evaluate the parasitoids (Trichogramma raoi, T. chilonis), predator (Chrysoperla cornea) and biopesticides i.e. botanicals (neem based Gronim) / mocrobials (Bacillus thuringensis and Beauveria bassiana ) against five major insect pests viz. Polytela gloriosae, Anomis flava, Earias vitella, Dysdercus cingulatus and Aphis gossypi of important target species of medicinal plants- Abelmoschus moschatus, Gloriosa superba and Withania somnifera in forest nursery, Tropical Forest Research Institute, Jabalpur and Delakhari west Chhindwara forest division, Madhya Pradesh (India). The results revealed that Bacillus thuringensis 1\% followed by neem based pesticide (Gronim) 1\% was found to be most effective against defoliators Polytela gloriosae on G. superba, Anomis flava and shoot/fruit borer Earias vitella on $A$. moschatus. Neem based pesticide (Gronim) followed by Bt $1 \%$ was found to be most effective against red bug Dysdercus cingulatus on the fruits of A. moschatus and aphid, Aphis gossypi on W. somnifera. Predator, Chrysoperla cornea@ 500 per 100 sq m followed by parasitoid Trichogramma chilonis@1500 per 100 sq m was also found to be most effective for reduction of the larval population of defoliators P. gloriosae and A. flava.
\end{abstract}

Keywords: Insect Pests, Medicinal Plants, Parasitoids, Predator and Biopesticides

\section{Introduction}

Muskdana, Abelmoschus moschatus (Medic.) [syn. Hibiscus abelmoschus (Linn.)] is considered as an important medicinal plant in Indian system of medicine and perfumery. Kalihari, Gloriosa superba (Linn.) is used under threatened plant species and used as tonic, stomachic, anthelmintic and having the most important alkaloid colchicine. Cluster winter cherry or ashwagandha, Withania somnifera (L.) Dunal, is a high value medicinal plant, extensively exploited in Indian system of medicine and used as an adaptive with antistress, antioxidant, antiflammatory, mind boosting and rejuvenating properties [24]. Central India (Madhya Pradesh, Chhattisgarh and Maharashtra states) is known for their rich diversity of medicinal plants. State Forest Departments through Minor Forest Produce Federations are encouraging farmers to take up medicinal plants for additional income. During cultivation of medicinal plants. The quality and quantity of raw materials obtained from the medicinal plants are adversely affected by the attack of number of insect pests in cultivated areas. Use of chemical pesticides is hazardous and causes environmental pollution. Therefore, environmentally safe biological pesticides are to be involved for the management of insect pests of important cultivated medicinal plants. These potential medicinal plants are always under serious threat of insect attack. The major insect pests of $A$. moschatus are defoliator, Anomis flava (Fab.), shoot / fruit borer, Earias vitella (Fab.), sap sucker, Dysdercus cingulatus (Fab.) and their incidence varies from 50-62.5, 30-70 and 70-90 per cent respectively $[1,8,15]$. While $W$. somnifera suffers attack by insect pests like white grub, Holotrichia serrata (Fab.), mealy bug, Coccidohystrix insolitus (Green.) and spotted leaf beetle, Epilachna vigintioctopunctata (Fab.) [14,22]. No specific information is available on the biological control of insect pests of target species of medicinal plants viz. $A$. moschatus, G. superba and W. somnifera. Hence, the present 
study was undertaken to investigate the biological control of major insect pests of target species of medicinal plants.

\section{Methodology}

Egg parasitoid, Trichogramma raoi was reared and multiplied in the laboratory of Forest Entomology Division, Tropical Forest Research Institute (ICFRE), Jabalpur, India. The cards of parasitoid, T. chilonis, and predator, Chrysoperla carnea were procured from the laboratory of Entomology, Agriculture College, Nagpur (Maharashtra, India) and released in the forest nursery (experimental plot) at TFRI, campus Jabalpur and Delakhari (West Forest Division, Chhindwara, Madhya Pradesh, India). The observations on the intensity of damage caused by two different insect pests i.e. defoliators, Polytela gloriosae on $G$. superba and Anomis flava on A. moschatus were taken in the parasitoid and predator released areas and compared with non released (control) plots.

The experiments on the efficacy of some biopesticides against the key insect pests were laid out in Randomized Block Design (RBD) with three replications. Biopesticides i.e. microbial agents- Bacillus thuringiensis, Beauveria bassiana, and botanicals- commercial neem based pesticides (Gronim) were tested for their efficacy against the key insect pests i.e. defoliator, Polytela gloriosae on Gloriosa superba; defoliator Anomis flava, shoot/fruit borer Earias vitella, fruit sucker/ red cotton bug, Dysdercus cingulatus on $A$. moschatus and leaf sap sucker / aphid, Aphis gossypi on $W$. somnifera. Data thus obtained were subjected to statistical analysis for better interpretations of results [4].

\section{Result and Discussion}

The results of the field experiments on the efficacy of different biopesticides against major insect pests are described separately.

\subsection{Effect of Selected Biopesticides Against Defoliators, Polytela gloriosae (Fab.) on G. superba and Anomis flava (Fab.) on A. moschatus}

The data pertaining to larval mortality are presented in Table 1 . The data pertaining to the mortality of larvae after 7 days of treatment revealed that all the four treatments were significantly superior over control in respect of larval mortality. Observations showed that the mortality of larvae of P. gloriosae varied from 13.33 to 73.33 per cent. The highest mortality of larvae was observed in the treatment T4 Bacillus thuringensis (Dipel) 1\% (73.33 per cent) followed by $\mathrm{T} 1$ Neem based (Gronim) 1\% (60.00 per cent). All the biopesticides tested, caused larval mortality of P. gloriosae. Among the treatments, Bacillus thuringensis (Dipel) $1 \%$ followed by Neem based (Gronim) 1\% was significantly superior. This trend was not recorded by [20], because the evaluation of insecticides against $P$. gloriosae was entirely different from those biopesticides tested in the present study. According to them chlorpyrifos 0.02 per cent and quinalphos $0.05 \%$ were proved most effective in rapidly killing $P$. gloriosae in laboratory conditions. Since the work was not done on the evaluation of biopesticides against $P$. goriosae. Use of biopesticides in medicinal plants for control of the insect pests [5]. The use of chemical insecticides be restricted in medicinal plants as they affect the quality of medicines [19].

In case of $A$. flava, Table 1 revealed that all the treatments were significantly superior when compared to untreated control in the protection of plants. The treatment $\mathrm{T} 4 \mathrm{~B}$. thuringensis $1 \%$ followed by $\mathrm{T} 1 \mathrm{Neem}$ based (Gronim) $1 \%$; T3 B. bassiana (Traps) $1 \times 10^{8}+$ Neem based (Gronim) $1 \%$ resulted in $72.22,69.44,69.44$, per cent larval mortality respectively. Treatments $\mathrm{T} 3$ and $\mathrm{T} 1$ found equally effective. Fenvalerate $0.01 \%$ was found to be most effective against defoliator, Anomis flava on A. moschatus [8].

Table 1. Effect of selected biopesticides against defoliators, Polytela gloriosae and Anomis flava.

\begin{tabular}{lll}
\hline \multirow{2}{*}{ Treatment } & \multicolumn{2}{l}{ Mean (\%) larval mortality after 7 days of treatment } \\
\cline { 2 - 3 } & P. gloriosae & A. flava \\
\hline T1. Neem based (Gronim) 1\% & 60.0 & 69.44 \\
T2. Beauvaria bassiana (Traps) $1 \times 10^{8}$ & 13.33 & 68.33 \\
T3. B. bassiana $1 \times 10^{8}+$ Neem based(Gronim) $1 \%$ & 26.66 & 69.44 \\
T4. Bacillus thuringensis (Dipel) $1 \%$ & 73.33 & 72.22 \\
T5. Control (Untreated) & 0.0 & 0.00 \\
S E \pm & 8.36 & 6.58 \\
CD at $5 \%$ & 19.29 & 14.35 \\
\hline
\end{tabular}

\subsection{Effect of Selected Parasitoid / Predator Against Defoliators, P. gloriosae and A. flava}

The data pertaining to per cent damaged plants and reduction of population of defoliator, $P$. gloriosae on $G$. superba are presented in Table 2. The per cent incidence on damaged plants and reduction of larval population varied from 10.56 to 30.32 per cent and 4.66 to 79.44 per cent respectively. The lowest per cent incidence of damaged plants and highest per cent reduction of larval population observed in plots released with T3 predator, Chrysoperla carnea (10.56 and 79.44 per cent) followed by T2 parasitoid Trichogramma chilonis (14.30 and 70.83 per cent). All the treatments were found to be significantly superior over untreated control. The lowest per cent incidence of damaged plants of G. superba and highest per cent reduction of larval population of $P$. gloriosae were observed in plots released with predator, Chrysoperla carnea@500/100 sq m followed 
by parasitoid Trichogramma chilonis and T. raoi@1500/sq m.T. chilonis@1.5lakh per hectare reduced fruit borer, Earias vitella damage in okra [3]. Release of T. chilonis comprised with other treatments reduced fruit borer infestation in okra [7]. Release of T.raoi@1.25 lakh / ha to minimize the attack of teak skeletonizer Eutectona machaeralis in in natural teak forest areas in west Mandla forest division, Madhya Pradesh [16]. Release of parasitoid and predator against defoliator, Polytela gloriosae was not reported on $G$. superba so far.

In case of $A$. flava, the data pertaining to per cent damaged plants and reduction of larval population of $A$. flava presented in Table 2. The per cent incidence on damaged plants and reduction of larval population varied from 13.45 to 23.20 per cent and 58.89 to 82.22 per cent respectively after 30 days of release of parasites and predator. The lowest per cent incidence of damaged plants and highest per cent reduction of larval population were observed in plots released with T3 predator, Chrysoperla carnea (13.45 and 82.22 per cent) followed by $\mathrm{T} 2$ parasitoid Trichogramma chilonis (18.25 and 71.03 per cent). All the treatments were found to be significantly superior over untreated control. The lowest per cent incidence of damaged plants of A. moschatus and highest per cent reduction of larval population of $A$. flava were observed in plots released with predator, Chrysoperla carnea@500 /100 sq m followed by parasitoid Trichogramma chilonis and T.raoi@1500/sq m. T. chilonis @1.5 lakh per hectare reduced fruit borer, Earias vitella of o damage in okra [3]. Release of T. chilonis comprised with other treatments reduced fruit borer infestation in okra [7]. ReleaseT.raoi@1.25 lakh / ha to minimize the attack of teak skeletonizer Eutectona machaeralis in in natural teak forest areas in west Mandla forest division, Madhya Pradesh, India [16]. Release of parasitoid and predator against defoliator, A. flava was not reported on A. moschatus so far.

Table 2. Effect of selected parasitoid/predator against defoliators, P. gloriosae and A. flava (after 30 days of treatment).

\begin{tabular}{lllll}
\hline \multirow{2}{*}{ Treatments } & Polytela gloriosae & & Anomis flava & \\
\cline { 2 - 5 } & \% Damaged plants & $\begin{array}{l}\text { \% reduction of larval } \\
\text { population }\end{array}$ & \% Damaged plants & $\begin{array}{l}\text { \% reduction of larval } \\
\text { population }\end{array}$ \\
\hline $\begin{array}{l}\text { T1. Parasitoid Trichogrmma raoi } \\
\text { (1500 eggs per 100 sqm.) }\end{array}$ & 18.37 & 46.66 & 23.20 & 58.89 \\
$\begin{array}{l}\text { T2. Parasitoid Trichograma chilonis } \\
\text { (1500 eggs per 100 sqm.) }\end{array}$ & 14.30 & 70.83 & 18.25 & 71.03 \\
$\begin{array}{l}\text { T3. Predator Chrysoperla cornea } \\
\text { (500 eggs per 100 sqm) }\end{array}$ & 10.56 & & & 82.22 \\
$\begin{array}{l}\text { T4. Control (Untreated) } \\
\text { SE m } \pm\end{array}$ & 30.72 & 79.44 & 13.45 & 0.00 \\
CD at 5\% & 1.96 & 0.00 & 55.98 & 7.74 \\
\hline
\end{tabular}

\subsection{Effect of Selected Biopesticides Against Shoot/Fruit Borer, Earias vitella (Fab.) on A. moschatus}

The data pertaining to shoot and fruit borer are presented in Table 3. All the treatments were found to be significantly superior over control in respect of infested shoots and fruits. The infestation of E. vitella on shoots and fruits varied from 7.90 to 25.38 and 10.28 to 28.55 per cent. The lowest infested muskdana shoots and fruits was observed in plots treated with treatment T1 Bacillus thuringensis 1\% (7.69 and 10.28 per cent ) followed by T3 Neem based (Gronim) $1 \%$ (8.30 and 12.90 per cent) as compared to control (untreated). Other treatments like release of predator Chrysoperla carnea, parasitoid Trichogramma chilonis and T. raoi also reduced the infestation of shoot and fruit borer as compared with control. The lowest infested shoots and fruits of $A$. moschatus was observed in plots treated with treatment Bacillus thuringensis $1 \%$ followed by Neem based (Gronim) 1\% as compared to control (untreated). Other treatments like release of predator Chrysoperla carnea, parasitoid Trichogramma chilonis and T. raoi also reduced the infestation of shoot and fruit borer as compared with control. Fenvalerate $0.01 \%$ was found to be most effective against shoot / fruit borer E. vitella in on A. moschatus [8]. Least bhendi fruit damage by $E$. vitella due to the application of Bacillus thuringiensis [10] . Release of $T$. chilonis comprised with other treatments reduced fruit borer infestation in okra $[3,5]$.

Table 3. Effect of selected biopesticides against shoot/fruit borer, Earias vitella.

\begin{tabular}{lll}
\hline \multirow{2}{*}{ Treatment } & \multicolumn{2}{l}{ Average \% infested shoot/fruits after 30 days of treatment } \\
\cline { 2 - 3 } & Shoot & Fruits \\
\hline T1. Bacillus thuringensis 1\% & 7.90 & 10.28 \\
T2. Trichogramma chilonis & 15.50 & 20.50 \\
T3. Neem based (Gronim) 1\% & 8.30 & 12.90 \\
T4. Trichogramma raoi & 12.90 & 18.28 \\
T5. Chrysoperla carnea & 11.54 & 15.52 \\
T6. Control (Untreated) & 25.38 & 28.55 \\
SE $m \pm$ & 0.54 & 0.55 \\
CD at 5\% & 1.58 & 1.63 \\
\hline
\end{tabular}




\subsection{Effect of Selected Biopesticides Against Red Bug, Dysdercus cingulatus (Fab.) on A. moschatus}

Table 4. Effect of selected biopesticides against Dysdercus cingulatus on A. moschatus.

\begin{tabular}{lll}
\hline \multirow{2}{*}{ Treatment } & \multicolumn{2}{l}{$\begin{array}{l}\text { Average \% reduction in } \\
\text { population after treatment }\end{array}$} \\
\cline { 2 - 3 } & 3 days & $\mathbf{7 \text { days }}$ \\
\hline T1. Bacillus thuringensis $0.5 \%$ & 15.05 & 30.15 \\
T2. B. thuringensis $1 \%$ & 34.04 & 49.64 \\
T3. Neem based (Gronim) $0.5 \%$ & 21.59 & 33.53 \\
T4. Neem based (Gronim) $1 \%$ & 66.00 & 83.01 \\
T5. Beauveria bassiana(Traps) $1 \times 10^{8}$ & 21.66 & 21.66 \\
T6. Control (Untreated) & 0.00 & 0.00 \\
SE m \pm & 7.724 & 6.764 \\
CD at 5\% & 16.830 & 14.739 \\
\hline
\end{tabular}

The data (Table 4) on field trial showed that all the treatments were significantly superior to those of the control in reducing the population of bug after 3 and 7 days of application. T4 Neem based (Gronim) $1 \%$ followed by T2 $B$. thuringensis $1 \%$ proved highly effective by reducing 66.00 , 83.01, 34.04, 49.64 per cent population of bug compared with untreated control. Among others T6 Beauveria bassiana 1\% T3 Neem based (Gronim) 0.5\%), T5 Beauveria bassiana (Traps) $0.7 \%$ and $B$. thuringensis $0.5 \%$ gave minimum bug population up to $23.33,36.94,21.59,33.53,21.66,15.05$, 30.15 per cent after 3 and 7 days of application respectively. Neem based (Gronim) 1\% followed by B. thuringensis 1\% was found superior to all other treatments for reduction of bug population after 3 and 7 days of treatment. Synthetic pyrethroid fenvalerate $0.01 \%$ and was found to be most effective against red cotton bug, Dysdercus cingulatus on $A$. moschatus [15]. The use of chemical insecticides should be restricted in medicinal plants as they deteriorate the quality of medicines [19]. Since the work was not done on the evaluation of biopesticides against $D$. cingulatus on $A$. moschatus.

\subsection{Effect of Selected Biopesticides Against Aphid Aphis gossypii (Glover) on $W$. somnifera}

The data presented in Table 5 revealed that the average reduction per cent of aphid population varied from 12.60 to 55.00 and 15.00 to 65.00 per cent per three leaves among the four biocontrol treatments which were significantly lower than the untreated (control). Highest population reduction of 55 and 65 per cent after 15 and 30 days of treatment was recorded in T2. Neem based (Gronim) 1\% followed by T1. Bacillus thuringensis 1\% (44.00 and 59.00 per cent) and T4. Chrysoperla carnea (20.30 and 35.00 per cent). All the treatments were found to be significantly superior over control in respect of per cent reduction of aphid population. Highest population reduction of aphid after 15 and 30 days of treatment was recorded in Neem based (Gronim) 1\% followed by Bacillus thuringensis 1\%. Neem, a phytopesticides obtained from Azadirachta indica is a safe pesticide. It proved good control against aphid. However, a suspension of neem seed was the best against Aphis gossypii in agriculture crops [2]. Similarly the highest mortality of aphid in Verticillium lecanii $0.3 \%$ compared to Neem seed kernel 4\% and dimethoate on Gerbera aphid, Myzus persicae [9].

Table 5. Effect of selected biopesticides against Aphis gossypii on W. somnifera.

\begin{tabular}{llc}
\hline Treatment & Average \% reduction in aphid population after treatment \\
\hline & 15 days & 30 days \\
T1. Bacillus thuringensis $1 \%$ & 44.00 & 59.00 \\
T2. Neem based (Gronim) $1 \%$ & 55.00 & 65.00 \\
T3. Beauveria bassiana(Traps) $1 \times 10^{8}$ & 12.60 & 15.00 \\
T4. Chrysoperla carnea (1500 eggs) & 20.30 & 35.00 \\
T5. Control (Untreated) & 0.00 & 0.00 \\
SE $\mathrm{m} \pm$ & 5.20 & 5.70 \\
CD at $5 \%$ & 12.70 & 13.62 \\
\hline
\end{tabular}

\section{Conclusion}

On the basis of field experiments it can be concluded that Bacillus thuringensis (Dipel) 1\% followed by neem based pesticide (Gronim) 1\% was found to be most effective against kalihari defoliator, P. gloriosae, muskdana defoliator, Anomis flava and shoot/fruit borer Earias vitella. Neem based pesticide (Gronim) followed by Bacillus thuringensis (Dipel) $1 \%$ was found to be most effective against red cotton bug/stainer, Dysdercus cingulatus on the fruits of $A$. moschatus and aphid, Aphis gossypi on Ashwagandha, Withania somnifera. Predator, Chrysoperla cornea@500 per $100 \mathrm{sq} \mathrm{m}$ followed by parasitoid Trichogramma chilonis @ 1500 per $100 \mathrm{sq} \mathrm{m}$ was also found to be most effective for reduction of the larval population of defoliator P. gloriosae on G. superba and A. flava on A. moschatus.

\section{Acknowledgement}

Authors are grateful to Dr. U. Prakasham, IFS, Director, Shri P. Subramanyam, IFS Group Co-ordinator (Research) and Dr. N. Kulkarni, Scientist-G, Head, Forest Entomology Division Tropical Forest Research Institute (ICFRE), Jabalpur, Madhya Pradesh, India for providing the necessary facilities for carrying out this study and encouragement financial support from ICFRE, Dehradun, India is also acknowledged. Authors are also grateful to the Divisional Forest Officers, West Forest Division, Chhindwara and south forest divisions Balaghat, Madhya Pradesh, India for providing the necessary field facilities. 


\section{References}

[1] Anon. (1985). "The Wealth of India: A Dictionary of Indian Raw Materials and IndustrialProducts". Raw Materials, Vol. 1 (Revised Edn.), 513 pp. Publication and Information Directorate. C.S.I.R., New Delhi, India .

[2] Asari, P.A.R.and M.R.G.K. Nair (2003). "On the control of brinjal pests using deterrents". Agric. Res. J. Kerala 10:133135. M. Gupta. Methods of biopesticides in medicinal plants against insect pests. Udhyamita 11: 42-43.

[3] Ghatge, S.M.(2002)."IPM of summer okra". M.Sc.(Agri.) thesis submitted to Mahatma Phule Krishi Vidhyapeeth, Rahuri, M.S.

[4] Gomez, A.K. and Gomez, A.A.(1984).Statistical Procedures for Agricultural Research. JOHN WILEY and SONS, Singapore. pp.130-138.

[5] Gupta, M. (2003). Methods of biopesticides in medicinal plants against insect pests. Udhyamita, 11(9):42-43.

[6] Hanumanthaswamy, B.C., D.Rajgopal, A.A. Farooqui and A.K Chakravarthy(1993). "Insect pests of Costus speciosus Linn. a medicinal plant". My Forest, 29: 158-160.

[7] Jadhav, S.S. (2003). "Integrated pest management of okra Abelmoschus esculentus". M.Sc.(Agri.) thesis submitted to Mahatma Phule Krishi Vidhyapeeth, Rahuri, M.S.

[8] Joshi, K.C., P.B. Meshram, S. Sambat, U. Kiran, S. Humne and G.K. Kharkwal (1992). "Insect pests of some medicinal plants in Madhya Pradesh". Indian J. Forestry, 15 : 17-26.

[9] Kadam, J.R., P. Mahajan and A.P. Chauhan (2008). "Studies on the potential of Verticilium lecanii against sucking pests of Gerbera". J. Maharashtra Agri. Univ., 33 :214-217.

[10] Kharbade, S.B.,A.G.Chandele and M.D. Dethe (2003). "Management of Earias vitella Fab. on summer okra with Bacillus thuringiensis varietal products". State level seminar on pest management for sustainable agriculture, MAU, Parbhani 24 pp.

[11] Kulkarni, S.S., K.V. Naik, V.N. Jalgaonkar and A.V. Rege (2008)."Survey of pest infestations on the important medicinal plants of Konkan region of Maharashtra". Pestology, 32 : 3133 .

[12] Kumar, H.R. (2007). "Survey of pests of medicinal plants with special reference to biology and management of Epilachna beetle, Henosepilachna vigintioctopunctata Fabricius (Coleoptera: Coccinellidae) on Ashwagandha". M.Sc. (Agri) Thesis, Uni. Agric. Sci., Dharwad.

[13] Mathur, A.C. and J.B. Srivastava (1996). "A noted list of the insect pests of important medicinal plants of Jammu \& Kashmir". Symposium on proearth Laboratory Jammu, 16 pp.

[14] Meshram, P.B.(2005)."New report of defoliator Psilogramma menephron on Rauvolfia serpentina and white grub, Holotrichia serrata on Withaniasomnifera". Indian Forester 131:969-970.

[15] Meshram, P.B and K.C. Choudhury (2000). "Effect of some insecticides against red cotton bug, Dysdercus cingulatus (Fabr.) on Abelmoschus moschatus Medic". Indian Perfumer, 44: 7-9.

[16] Meshram, P.B., N. Roychoudhury M. Yousuf and R.K. Malviya (2013). "Efficacy of indigenous egg parasitoid Trichgramma raoi against teak skeletonizer Eutectona machaeralis (Lepidoptera : Pyralidae)". Indain J. Trop. Biodiv., 21(1\&2):129-134.

[17] Muralibaskaran, R.K., D.S. Rajavel and K. Suresh (2009). "Yield loss by major insect pests in Ashwagandha". Insect Environ 14: 149-151.

[18] Oudhia, P. (2001). "First record on orange banded blister beetle, Zonabris putulata on safed musli". Nat. Res. Seminar on herbal conservation, cultivation, marketing and utilization with special emphasis on Chhattisgarh, 82 p, 13-24 December,

[19] Oudhia, P. (2006). "Traditional medicinal knowledge about Polytela gloriosae Fab. (Lepidoptera: Noctuidae) feeding on kalihari (Gloriosa superba) in Chhattisgarh, India". http;// www.ecoport.org

[20] Patel, V.C. and Patel, H.K.(1967). Chemical control of Polytela gloriosae(F.) on ornamental lilies. Indian Journal of Entomology, 29(4):397.

[21] Rai, S.N. and J. Singh. (1996). "Biology and chemical control of carmine spider mite, Tetranychus cinnabarinus (Boiso.) (Acarina: Tetranychidae) on Ashwagandha, Withania somnifera". Pestology 20 11: 23-27.

[22] Ravikumar, A. R. Rajendran, C. Chinnaih, S. Irulandi and R. Pandi (2008). "Evaluation of certain organic nutrient sources against mealy bug, Coccidohystrix insolitus (Green.) and the spotted leaf beetle, Epilachna vigintioctopunctata (Fab.) on Ashwagandha, Withania somnifera". J. Biopesticides 1: 28-31.

[23] Singh, A.K (2006). "Flower Crops: Cultivation and Management". Published by M/S New India, Publishing Agency, Delhi, 463 pp.

[24] Singh, R.H., S.K. Nath and P.B. Behere (1990)."Depressive illness a therapeutic evaluation with herbal drugs". $J$. Research in Ayurvedha and Siddha, 11: 1-6.

[25] Talukder, D., A.R. Khan and M. Hasan (1989)."Growth of Diacrisia obliqua (Lep : Arctiidae) with low doses of Bacillus thuringiensis var. kurstaki)". BioControl 34: 587-589. 